\title{
Science cements Chinese ties
}

tor of the National Science Foundation (NSF).

"There are literally hundreds of people out there who, with a modest add-on to their existing NSF grant, could adopt research groups in the former Soviet Union", Pines says. "The money could be used to fly them here, bring them up to date, and arrange a mutually beneficial collaboration on a significant problem once they return to Russia. The point is to get a great number of people over here, as quickly as possible."

As with all recommendations that ask for more, the chief question is how to pay for it. Using money from the special fund set up last fall is attractive for two reasons: it protects the budgets of domestic research agencies, and it relies on money already appropriated.

But at a time when millions of US workers are unemployed and the federal deficit is approaching $\$ 400,000$ million, the notion of foreign aid is not a popular one. Recognizing that fact, those who attended the workshop hasten to explain that such a programme would benefit the United States as much as it helps the former Soviet Union.

"In order to have a free market in the former Soviet Union, which we want to foster, you need a strong science and technology base", explains Glenn Schweitzer, an expert on Central and Eastern Europe at the academy. "We also want to keep weapons scientists in place, working on civilian projects, instead of letting them go off and work for somebody that could threaten us. In addition, if we don't do it, the Japan and the Europeans will." Jeffrey Mervis

\section{Jerusalem}

ISRAEL has taken advantage of the high standing of its scientists in China to bring about full diplomatic relations between the two countries.

THE opening of a fụlly staffed embassy in Beijing in January ends a 40-year diplomatic silence between the two countries. Although in the mid-1980s China began to accept tourists visiting on group visas, scientists were the only Israelis permitted to enter the country on individual visas. Despite the official cold shoulder shown to most of their countrymen, these scientists were greeted warmly by their Chinese colleagues.

Reuven Merhav, an Israeli diplomat who had worked in Hong Kong, decided to put that affection to the test shortly after being appointed director-general of the Israeli Foreign Ministry in November 1988. He asked Joshua Jortner, president of the Israel Academy of Sciences, and its director, MeirZadok, if the academy would like to establish an Israeli scientific centre in China. The academy officials quickly agreed, and in May 1989 they dispatched a three-person team to Beijing to sound out leading members of the Chinese scientific community.

The trip was a success. "They thought we were a scientific superpower," Zadok says with a laugh. In fact, Zeev Tadmor, a chemist who is now head of the Technion in Haifa, discovered that an undergraduate textbook he wrote with C.G. Gogos, Principles of Polymer Processing, had

\section{BIOTECHNOLOGY}

\section{'Silber's folly' goes public}

Boston University (BU) will learn later this month what investors think of its controversial decision to invest nearly $\$ 100$ million over the past five years in a small biotechnology company.

The Hopkinton, Massachusetts, company, Seragen Inc., is preparing its first public offer of three million shares -25 per cent of the company. If successful, the offer will raise enough money to support the company for the next 30 months and derive a product from its technology, which uses genetically engineered fusion toxins to kill disease-carrying cells. It will also enable the university to end its monthly infusion of $\$ 1.2$ million into the company, drawn from the school's endowment.

If the stock market responds as well as $\mathrm{BU}$ is predicting, university president John Silber will have proved wrong the critics of his 1987 decision to invest the equivalent of one-fifth of the university's endowment in the company. With shares priced at between $\$ 17$ and $\$ 20$ each, Seragen would be worth $\$ 166$ million on paper - almost $\$ 70$ million more than BU has invested.

But Wall Street may not see it the same way. Peter Drake, an analyst with Vector Securities International, points out that eight of the 11 biotechnology companies that have gone public so far this year failed to get their asking price. As a group, they are now trading at an average of ten per cent under their initial value. Compared to last year's biotechnology gold rush, he says, "the class of 1992 are underproducers".

Whatever the outcome, BU says it is not baling out of Seragen. Even after the stock sale, the university will still own almost 70 per cent of the company. Nor, officials say, has the university lost confidence in the company's commercial promise, despite the potential damage from the outcome of patent infringement claims filed by two companies and the possibility that the attorney general of Massachusetts could decide that the university's investment is not prudent and force BU to sell its shares. been translated into Chinese and was being widely used.

A few days after the Israelis returned home, Chinese tanks rolled into Tiannanmen Square to suppress the student uprising. Although China's use of military force against its own citizens invoked a strong reaction from the international scientific community, it proved to be a boon to the deepening Israeli-Chinese relationship. In fact, Israeli officials believe that China reacted with uncharacteristic speed to their political overtures in part to counteract their feelings of isolation brought on by sanctions imposed by much of the rest of the world.

As a result, what was expected to take years bore fruit in a matter of months. In November, Merhav and Zadok flew to New York to meet Li Lu Ye, the Chinese ambassador to the United Nations. They agreed that the Israeli academy would set up a liaison office in Beijing and that China would open a tourism office in Tel Aviv. The Israeli office - the first official Israeli presence in China - opened in April 1990. It was headed by Yossi Shalhevet, a 60-year-old agronomist and former director of the Volcani Research Institute.

"He's straightforward and he's warm," says Zadok about Shalhevet. "He's probably the best diplomat that Israel has."

Shalhevet says that the Chinese especially admire Israel's military prowess and its success in making the desert bloom. "They attribute our successes to the use of science and technology, which today is the highest priority in China," he says.

Once he arrived in Beijing, Shalhevet began to tour universities and scientific institutions throughout China. He paved the way for 100 Israeli scientists to visit China, and likewise for 50 Chinese scientists to tour Israel. He began a student exchange program and initiated research symposia.

Building upon his success, Merhav again met the Chinese ambassador to the UN in October 1990. He argued that the forthcoming peace talks on the Middle East required the posting of an experienced diplomat in its Chinese liaison office. The Chinese agreed, and last year an Israeli diplomat joined Shalhevet.

The multinational peace conference in Moscow last December further accelerated the process. Israel agreed to China's wish to participate in the talks only after China acceded to its request for full diplomatic relations.

Shalhevet remains in the Beijing office as scientific liaison. He says he is now busier than ever, bringing together business officials as well as arranging visits to Israel by Chinese scientists and students.

Abraham Rabinovich 